BISMA - Bisnis dan Manajemen -Volume 9 No. 1 Oktober 2016

\title{
PENGARUH KUALITAS LAYANAN TERHADAP LOYALITAS PELANGGAN MELALUI KEPUASAN PELANGGAN SEBAGAI VARIABEL INTERVENING (STUDI PADA PELANGGAN DUNKIN' DONUTS DI SURABAYA DAN SIDOARJO)
}

\author{
Kiki Amelia Nurmala Dewi \\ Jurusan Manajemen, Fakultas Ekonomi, Universitas Negeri Surabaya \\ kikiamelianurmaladewi@yahoo.com
}

\begin{abstract}
The purpose of this study is to find out is there any influence of service quality on customer loyalty through customer satisfaction as intervening variable on customer Dunkin' Donuts in Surabaya and Sidoarjo. This research using nonprobability sampling with judgemental sampling as sampling category. This research take 220 people as a respondents of the sample object. The respondents of this research is the customer Dunkin 'Donuts men and women aged 18-50 years who have made a purchase and consume directly at the Dunkin' Donuts at least 2 times in the last 3 months. The instruments used is an observation, documentation, interview and questionnaire that analyzed using a Likert scale. Analysis of data using path analysis. The result of this research showed that there is any influence of service quality on customer loyalty through customer satisfaction as intervening variable.
\end{abstract}

Keywords: Service Quality, Customer Satisfaction, Customer Loyalty.

\section{PENDAHULUAN}

Di tengah meningkatnya persaingan dalam dunia bisnis yang terus terjadi sektor industri yang tidak pernah mengalami penurunan adalah industri makanan dan minuman. Menurut Kemenprin industri makanan, minuman, dan tembakau tercatat sebagai penyumbang PDB terbesar terhadap total PDB industri pengolahan nonmigas sejak tahun 2008. Kontribusi tersebut terus melonjak dari sebelumnya 30,4\% pada tahun 2008 menjadi 35,76\% pada 2013 dan 37,94\% pada kuartal III-2014 terus menunjukkan peningkatan. (www.kemenperin.go.id/artikel/10589/TargetPertumbuhan-Industri-2015-Dipangkas-Jadi-6,1)

Salah satu sektor usaha di industri makanan dan minuman yang sekarang sedang berkembang pesat di Indonesia adalah bisnis waralaba. Komisaris Pendidikan Asosiasi Franchise Indonesia (AFI) menjelaskan bahwa bisnis waralaba memiliki prospek yang menjanjikan dengan perputaran uang juga sangat signifikan dan masih akan menjadi bisnis yang paling diminati di tengah dinamika perdagangan. Berdasarkan data Direktorat Bina Usaha Kementerian Perdagangan dan juga asosiasi, sampai sekarang tercatat ada 23.000 gerai waralaba dari 12.000 pelaku usaha di Indonesia dengan pendapatan lebih dari 120 triliun di tahun 2014. Bisnis waralaba pada kuartal 1 ditahun 2015 ini juga sudah meluas ke berbagai kota di Indonesia. Bisnis waralaba tidak mengalami penurunan di tengahtengah kondisi perekonomian yang terjadi sekarang ini baik global ataupun bangsa ini, bahkan Perhimpunan Waralaba dan Lisensi Indonesia (WALI) sangat optimis akan bisnis dari waralaba ini dapat meningkatkan perekonomian
Indonesia. (http://beritadaerah.co.id/2015/08/27/bisniswaralaba-bertumbuh-mencapai-20-tahun-2015/)

Salah satu yang termasuk dalam bisnis waralaba industri makanan dan minuman yaitu bisnis bakery. Bakery adalah produk makanan yang bahan baku utamanya berasal dari tepung (mayoritasnya terigu). Dalam proses pengolahannya melibatkan pemanggangan. Berbagai makanan yang masuk ke dalam kategori bakery yaitu bagel, bread crumb, biskuit, croissant, cookies, cracker, donat, muffin, pancake, pastry, pies, pizza, pretzel, roll, dan wafer..

Sebagian besar konsumsi tepung terigu di Indonesia digunakan pada industri bakery. Sehingga dapat dilihat bahwa bakery cukup digemari oleh masyarakat di Indonesia. Hal ini tidak terlepas dari berubahnya tren gaya hidup masyarakat yang kini berkembang sehingga membuat masyarakat lebih suka mengkonsumsi berbagai produk bakery yang lebih praktis dan terlihat modern. Hal ini menjadikan peluang dalam bisnis ini terbuka lebar. Bisnis bakery merupakan salah satu bisnis yang menjanjikan, sehingga banyak pelaku usaha yang tertarik untuk turut serta bersaing dalam menjalankan bisnis ini.Banyaknya merek toko bakery yang beroperasi menjadikan persaingan toko bakery yang satu dengan yang lainnya tidak dapat dihindarkan. Hal ini menjadikan semakin beragamnya pilihan konsumen dalam memilih toko bakery. Konsumen dihadapkan pada berbagai pertimbangan dalam berperilaku untuk melakukan pengambilan keputusan. Perilaku pembelian konsumen melalui tahap informasi, evaluasi alternatif, pembelian, dan hasil (Engel et. al, 1995:141). Dari 
Kiki Amelia Nurmala Dewi - Pengaruh Kualitas Layanan Terhadap Loyalitas ...

hasil akan diperoleh kepuasan atau ketidakpuasan konsumen sehingga konsumen akan melakukan pembelian ulang dan menjadi loyal atau tidak. Menurut Griffin (2005:18) setiap pelanggan yang melakukan pembelian maka pelanggan tersebut bergerak melewati siklus pembelian dimulai dari kesadaran, pembelian awal, evaluasi pascapembelian, keputusan membeli kembali, dan pembelian kembali. Berbagai toko donat yang bermunculan dengan berbagai kualitas layanan yang ditawarkan menyebabkan persaingan dalam bidang usaha sejenis. Berikut adalah tabel TBI (Top Brand Index)

Tabel 1 TBI Kategori Toko Donat 2013-2015

\begin{tabular}{|l|l|l|l|l|l|}
\hline Merek & TBI & Merek & TBI & Merek & TBI \\
& 2013 & & 2014 & & 2015 \\
\hline Dunkin' Donuts & $49,0 \%$ & Dunkin' Donuts & $47,9 \%$ & J.CO & $57.2 \%$ \\
\hline J.CO & $45,3 \%$ & J.CO & $46,2 \%$ & Dunkin Donuts ' & $37.6 \%$ \\
\hline Primadona & $1,1 \%$ & Country Style & $1,3 \%$ & & \\
\hline & & Primadona & $1,3 \%$ & & \\
\hline
\end{tabular}

Sumber : Top Brand Index Fase 2, Diolah peneliti

Dari tabel 1 diatas dapat dilihat bahwa pada tahun 2013 sampai 2014 Dunkin' Donuts menjadi brand toko donat nomor 1 dengan persentase Top Brand Index yang cukup tinggi yaitu 49,0\% di tahun 2013 dan 47,9\% di tahun 2014, namun pada tahun 2015 Dunkin' Donuts mengalami penurunan persentase Top Brand Index menjadi hanya $37,6 \%$ dan penurunan urutan menjadi nomor 2 dikalahkan oleh pesaingnya yaitu J.CO dengan presentase yang cukup jauh perbedaannya. Padahal diketahui bersama bahwa Dunkin' Donuts merupakan pioneer toko donat di Indonesia yang telah banyak digemari oleh masyarakat di Indonesia.
Hal ini mengindikasikan bahwa salah satu parameter pengukuran TBI yaitu future intention mengalami penurunan sehingga minat pembelian pelanggan dimasa yang akan datang menurun. Dengan kata lain dapat dikatakan juga bahwa loyalitas pelanggan dari Dunkin' Donuts menurun.

Namun hasil ini berbeda dengan hasil survei yang dilakukan oleh JAKPAT, Pada tahun 2015 lembaga survei Jajak Pendapat (JAKPAT) melakukan survei mengenai persaingan antara dua toko donat yang ada di Indonesia yaitu Dunkin' Donuts dan J.CO. Berikut hasil survei pelanggan mengenai Dunkin' Donuts vs J.CO dari JAKPAT :

Tabel 2 Hasil Survei Dunkin' Donuts vs J.CO

\begin{tabular}{|l|l|l|}
\hline & Dunkin' Donuts & J.CO \\
\hline Konsumen menyukai layanan & $83 \%$ & $76 \%$ \\
\hline
\end{tabular}

Sumber : JAKPAT- Mobile Survey Platform Indonesia, Diolah Peneliti

Dari tabel 2 di atas menunjukkan kepuasan akan layanan yang diberikan oleh Dunkin' Donuts juga disebutkan lebih disenangi oleh Konsumen dibandingkan pesaingnya yaitu J.CO dengan persentase $83 \%$ vs $76 \%$. Dari data-data di atas menunjukkan adanya kesenjangan yang terjadi dimana hasil survei Top Brand Index Dunkin' Donuts mengalami penurunan dari kombinasi top of mind, last used, dan future intention menurut Frontier sehingga dapat dipastikan salah satu parameter pengukurannya yaitu future intention atau niat pembelian di masa mendatang oleh konsumen menurun. Padahal data yang dihimpun oleh lembaga survei JAKPAT (Jajak Pendapat) yang menunjukkan bahwa konsumen lebih menyenangi layanan yang dibeikan oleh Dunkin' Donuts dibandingkan pesaingnya yaitu J.CO.

Dunkin' Donuts memiliki banyak gerai di Indonesia khususnya di kota-kota besar salah satu nya seperti di Surabaya dan sekitarnya. Penulis memilih untuk melakukan penelitian di Dunkin' Donuts yang berada di Surabaya dan
Sidoarjo karena dua kota ini merupakan kota metropolitan yang memiliki banyak penduduk dengan gaya hidup modern, mengutamakan kepraktisan, dan juga penduduk kota metropolitan lebih senang menghabiskan waktunya untuk berkumpul bersama teman atau keluarga ditempattempat ramai sejenis cafe. Tak jarang pula untuk urusan pekerjaan seperti bertemu kolega dilakukan pertemuan di cafe maupun restoran. Gaya hidup seperti ini sesuai dengan konsep dari Dunkin' Donuts yang dibentuk menjadi gerai (konsepnya sama dengan cafe) agar dapat memenuhi permintaan dari para konsumennya dan juga konsep gerai dibuat sebagai strategi dalam memenangkan persaingan dengan memberikan perbedaan kualitas layanan dibandingkan dengan para pesaing dalam bidang usaha sejenis, karena dalam bidang jasa kualitas layanan merupakan hal yang sangat dipertimbangkan.

Dari latar belakang tersebut, maka dapat dirumuskan permasalahan sebagai berikut (1) Adakah pengaruh kualitas layanan terhadap kepuasan pelanggan pada pelanggan 


\section{BISMA - Bisnis dan Manajemen -Volume 9 No. 1 Oktober 2016}

Dunkin' Donuts di Surabaya dan Sidoarjo?, (2) Adakah pengaruh kepuasan pelanggan terhadap loyalitas pelanggan pada pelanggan Dunkin' Donuts di Surabaya dan Sidoarjo?, (3) Adakah pengaruh kualitas layanan terhadap loyalitas pelanggan pada pelanggan Dunkin' Donuts di Surabaya dan Sidoarjo?

Dari latar belakang dan rumusan masalah tersebut, maka tujuan penelitian ini adalah (1) Untuk menganalisis dan membahas pengaruh kualitas layanan terhadap kepuasan pelanggan pada pelanggan Dunkin' Donuts di Surabaya dan Sidoarjo. (2) Untuk menganalisis dan membahas pengaruh kepuasan pelanggan terhadap loyalitas pelanggan pada pelanggan Dunkin' Donuts di Surabaya dan Sidoarjo. (3) Untuk menganalisis dan membahas pengaruh kualitas layanan terhadap loyalitas pelanggan pada pelanggan Dunkin' Donuts di Surabaya dan Sidoarjo.

\section{KAJIAN PUSTAKA DAN PENGEMBANGAN HIPOTESIS}

\section{Kualitas Layanan}

Menurut Lupiyoadi (2014:212) kualitas layanan adalah sebagai hasil kegiatan distribusi dan logistik, dimana pelayanan diberikan kepada konsumen untuk mencapai kepuasan. Menurut Kotler (2009:143) kualitas layanan adalah setiap kegiatan atau manfaat yang dapat diberikan suatu pihak kepada pihak lainnya yang pada dasarnya tidak berwujud dan tidak pula berakibat kepemilikan sesuatu dan produksinya dapat atau tidak dapat dikaitkan dengan suatu produk fisik. Berdasarkan beberapa definisi diatas, kualitas layanan adalah suatu keseluruhan ciri dan karekteristik yang dimiliki suatu produk/jasa yang dapat memberikan kepuasan konsumen. Walaupun kualitas layanan lebih sulit didefinisikan dan dinilai dari pada kualitas produk, pelanggan tetap akan memberikan penilaian terhadap kualitas layanan, dan perusahaan perlu memahami bagaimana sebenarnya harapan pelanggan sehingga perusahaan dapat merancang jasa yang ditawarkan secara efektif.

Menurut Parasuraman dkk (1998, dalam Lupiyoadi 2014:216) disimpulkan terdapat lima dimensi kualitas layanan yaitu sebagai berikut: Berwujud (tangible), Reliabilitas, Ketanggapan (responsiveness), Jaminan dan kepastian (assurance), Empati (empathy). Dalam penelitian ini pengukuran variabel kualitas layanan menggunakan indikator pengukuran menurut Ramseook \& Munhurrun (2012), Ivanauskienė \& Volungėnaitė (2014), dan Aryani \& Rosinta (2010) yaitu : Tangibles, Emphaty, Reliability, Responsiveness, dan Assurance.

\section{Kepuasan Pelanggan}

Menurut Engel et. al (1995:210) didefinisikan sebagai evaluasi pascakonsumsi bahwa suatu alternatif yang dipilih setidaknya memenuhi atau melebihi harapan. Singkatnya, alternatif tersebut setidaknya bekerja sebaik yang diharapkan. Menurut Irawan (2002:20) Kepuasan (satisfaction) berasal dari bahasa latin yaitu satis yang berarti enough atau cukup dan facio yang berarti to do atau melakukan, sehingga kepuasan dapat diartikan sebagai upaya pemenuhan sesuatu atau membuat sesuatu memadai. Sebuah kepuasan juga bisa didefinisikan sebagai persepsi terhadap sesuatu yang telah memenuhi harapannya. Oleh karena itu, seseorang tidak akan puas apabila mempunyai persepsi bahwa harapannya belum terpenuhi. Seseorang akan merasa puas jika persepsinya sama atau lebih besar dari yang diharapkan. Menurut Kotler (2009:138) kepuasan (satisfaction) adalah perasaan senang atau kecewa seseorang yang timbul karena membandingkan kinerja yang dipresepsikan produk (atau hasil) terhadap ekspektasi mereka. Jika kinerja gagal memenuhi ekspektasi maka pelanggan akan tidak puas. Jika kinerja sesuai dengan ekspektasi, maka pelanggan akan sangat puas.Menurut definisi-definisi di atas dapat disimpulkan bahwa kepuasan merupakan perbedaan antara harapan sebelum pembelian dengan hasil kinerja yang diterima setelah pembelian. Sehingga dapat disimpulkan dari pengertian pengertian di atas bahwa kepuasan pelanggan merupakan perbandingan yang dirasakan pelanggan antara harapan pelanggan sebelum melakukan pembelian dengan hasil kinerja produk dan jasa yang diterima setelah melakukan pembelian.

Menurut Tjiptono \& Diana (2015:43) kepuasan pelanggan berdampak signifikan pada sejumlah aspek berikut : Niat beli ulang, Loyalitas pelanggan, perilaku komplain, dan gethok tular positif. Dalam penelitian ini pengukuran variabel kepuasan pelanggan menggunakan indikator pengukuran menurut Sachro (2013), Aryani \& Rosinta (2010), dan Sasongko \& Subagio (2013) yaitu sebagai berikut : Tidak ada keluhan, Perasaan puas pelanggan pada keseluruhan produk atau jasa, Kesesuaian dengan harapan pelanggan, dan Harapan pelanggan yang terlampaui

\section{Loyalitas Pelanggan}

Menurut Shert \& Mittal (dalam Tjiptono \& Chandra 2007:387) mengemukakan loyalitas pelanggan adalah komitmen pelanggan terhadap suatu merek, toko, dan pemasok, berdasarkan sikap yang sangat positif dan tercermin dalam pembelian ulang yang positif. Menurut Griffin (2005:5) konsep loyalitas pelanggan lebih banyak dikaitkan dengan perilaku (behavior) daripada dengan sikap. Bila seseorang merupakan pelanggan loyal, ia menunjukkan 
Kiki Amelia Nurmala Dewi - Pengaruh Kualitas Layanan Terhadap Loyalitas ...

perilaku pembelian yang didefinisikan sebagai pembelian nonrandom yang diungkapkan dari waktu ke waktu oleh beberapa unit pengambilan keputusan. Menurut Oliver dalam Hurriyati (2010:129) : "loyalitas adalah komitmen pelanggan bertahan secara mendalam untuk berlangganan kembali atau melakukan pembelian ulang produk/jasa terpilih secara konsisten dimasa yang akan datang, meskipun pengaruh situasi dan usaha-usaha pemasaran mempunyai potensi untuk menyebabkan perubahan perilaku". Sehingga dapat disimpulkan bahwa loyalitas secara umum dapat diartikan sebagai kesetiaan seseorang atas suatu produk, baik barang maupun jasa tertentu. Selain itu pelanggan yang memiliki komitmen tinggi atas loyalitasnya tidak akan terpengaruh oleh bentuk-bentuk pemasaran produk atau jasa yang diberikan perusahaan lain dan akan terus memilih produk dan jasa yang mereka pilih sebelumnya. Loyalitas pelanggan akan menjadi kunci sukses, tidak hanya dalam jangka pendek, tetapi keunggulan bersaing yang berkelanjutan.

Menurut Griffin (2005:31) loyalitas dapat didefinisikan berdasarkan perilaku membeli. Ciri- ciri pelanggan yang loyal adalah orang yang : Melakukan pembelian berulang secara teratur, Membeli antarlini produk dan jasa, Mereferensikan kepada orang lain, dan menunjukkan kekebalan terhadap tarikan dari pesaing. Dalam penelitian ini pengukuran variabel loyalitas pelanggan penulis menggunakan indikator menurut Andreani et. al (2012) dan Irawan \& Japarianto (2013) yaitu : Pembelian Ulang, Rekomendasi, dan Tidak mudah dipengaruhi oleh merek lain.

Berdasarkan uraian tersebut, peneliti menggunakan tiga hipotesis, yaitu :

H1: Kualitas layanan berpengaruh positif dan signifikan terhadap kepuasan pelanggan pada pelanggan Dunkin' Donuts di Surabaya dan Sidoarjo.

$\mathrm{H} 2$ : Kepuasan pelanggan berpengaruh positif dan signifikan terhadap loyalitas pelangga pada pelanggan Dunkin' Donuts di Surabaya dan Sidoarjo.

H1: Kualitas layanan berpengaruh positif dan signifikan terhadap loyalitas pelanggan pada pelanggan Dunkin' Donuts di Surabaya dan Sidoarjo.

\section{METODE PENELITIAN}

Jenis rancangan penelitian yang digunakan dalam penelitian ini adalah rancangan riset konklusif dengan pendekatan deskriptif. Adapun rancangan penelitian yang dibuat oleh peneliti adalah untuk mengetahui apakah kualitas layanan berpengaruh terhadap loyalitas pelanggan melalui kepuasan pelanggan sebagai variabel intervening studi pada pelanggan Dunkin' Donuts di Surabaya dan Sidoarjo, dapat dilihat pada gambar berikut

Gambar 1 : Rancangan Penelitian

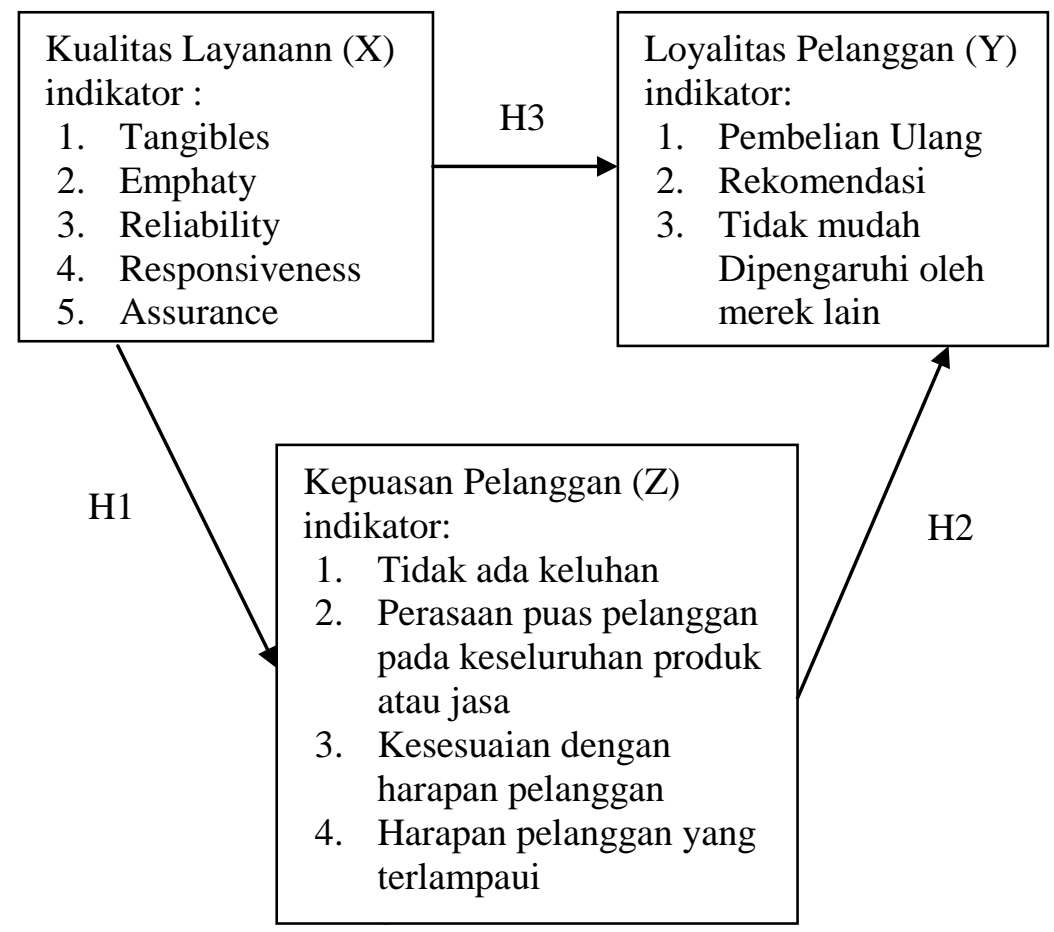




\section{BISMA - Bisnis dan Manajemen -Volume 9 No. 1 Oktober 2016}

\section{Sumber: Diolah peneliti}

Adapun lokasi yang digunakan sebagai objek penelitian adalah beberapa gerai Dunkin' Donuts yang berada di Surabaya dan Sidoarjo yakni Dunkin' Donuts Kedung Cowek, Dunkin' Donuts Ngagel, Dunkin' Donuts Basuki Rahmat, Dunkin' Donuts Graha Pena, dan Dunkin' Donuts A.Yani Sidoarjo.

Populasi yang menjadi target penelitian ini adalah Pelanggan Dunkin' Donuts laki-laki dan perempuan yang berusia 18-50 tahun dan telah melakukan pembelian produk Dunkin' Donuts dan mengkonsumsi secara langsung pada gerai Dunkin' Donuts minimal 2 kali pada 3 bulan terakhir. Jumlah populasi dalam penelitian ini tidak diketahui sehingga bersifat infinite.

Jumlah sampel yang akan dijadikan responden dalam penelitian ini sebanyak 200 berdasarkan jenis studi yang ada kaitannya dengan riset penyelesaian masalah sesuai dengan pendapat Malhotra (2009:369). Untuk mengantisipasi agar jumlah target terpenuhi, peneliti menambahkan $10 \%$ dari ukuran sampel hal ini mengantisipasi jika terdapat responden yang tidak dapat dihubungi atau tidak mau memberikan jawaban (Sarwono dan Martadiredja, 2008:147) sehingga jumlah sampel menjadi 220 responden. Teknik pengambilan sampel yang digunakan adalah nonprobability sampling, dengan metode pengambilan sampel judgemental sampling.

Jenis dan dan sumber data dalam penelitian ini ada dua yaitu data primer diperoleh langsung melalui jawaban dari responden melalui pengisian angket yang disebarkan oleh peneliti. Kedua yaitu data sekunder berupa buku literature, jurnal, dan artikel yang terkait dengan kualitas layanan, kepuasan pelanggan, dan loyalitas pelanggan pada pelanggan Dunkin' Donuts di Surabaya dan Sidoarjo.

Teknik pengumpulan data yang digunakan dalam penelitian ini dilakukan dengan 4 cara yakni Observasi, berupa pengamatan adanya fenomena yang terjadi mengenai kualitas layanan Dunkin' Donuts yang disenangi pelanggan, kepuasan yang dirasakan pelanggan, dan adanya penurunan loyalitas dari para pelanggan kepada Dunkin' Donuts. Dokumentasi, berupa mencari dan mencatat data sebanyakbanyaknya mengenai survei dari TBI tentang loyalitas pelanggan Dunkin' Donuts yang mengalami penurunan di tahun 2015. Survei dari website Dunkin' Donuts mengenai kenaikan persentase kepuasan akan kualitas layanan pelanggan Dunkin' Donuts di tahun 2015, dan juga survei dari JAKPAT mengenai kualitas layanan Dunkin' Donuts yang disenangi oleh para pelanggan dibandingkan pesaingnya di tahun 2015. kemudian Wawancara, berupa pengajuan pertanyaan terbuka yang dilakukan untuk mendapatkan data diri dari responden dan memastikan bahwa responden memiliki kriteria-kriteria yang ditetapkan oleh peneliti. Yaitu pelanggan Dunkin' Donuts telah melakukan pembelian minimal 2 kali pada 3 bulan terakhir dan telah mengkonsumsinya di gerai Dunkin' Donuts, dan yang terakhir Penyebaran angket, Digunakan untuk mendapatkan data primer dari responden, di mana di dalam angket terdapat beberapa pernyataan dan jawaban yang telah disediakan oleh peneliti sehingga responden dapat memilih jawaban dari pilihan yang disediakan. Peneliti menyebar angket kepada 220 responden yang berisi pernyataan tentang kualitas layanan, kepuasan pelanggan, dan loyalitas pelanggan.

\section{HASIL DAN PEMBAHASAN}

Teknik analisis data menggunakan analisi jalur atau path analysis. Sebelum melakukan analisis data, harus terlebih dahulu melakukan uji validitas dan reliabilitas.Hasil uji validitas dinyatakan valid karena memilikinilai Corrected Item - Total Correlation lebih besar dari 0,361. Sedangkan hasil uji relabilitas memiliki nilai Cronbach Alpha yang lebih besar 0,70, sehingga dapat disimpulkan bahwa pernyataan pada instrument penelitian (angket) reliabel dan dapat digunakan sebagai alat ukur untuk penelitian.

\section{Karakteristik Responden}

Responden dalam penelitian ini adalah pelanggan Dunkin' Donuts laki-laki dan perempuan yang berusia 18-50 tahun dan telah melakukan pembelian produk Dunkin' Donuts dan mengkonsumsi secara langsung pada gerai Dunkin' Donuts minimal 2 kali pada 3 bulan terakhir, dengan jumlah sebanyak 220 orang responden. Deskripsi karakteristik responden berdasarkan jenis kelamin dan usia.

Tabel 3 Karakteristik Responden

\begin{tabular}{|l|l|l|l|}
\hline \multicolumn{2}{|l|}{ Karakteristik Responden } & Jumlah & Presentase \\
\hline \multirow{3}{*}{ Jenis } & & & \\
Kelamin & Laki-Laki & 76 & $34,5 \%$ \\
& Perempuan & 144 & $65,5 \%$ \\
\hline & Total & 220 & $100 \%$ \\
\hline
\end{tabular}


Kiki Amelia Nurmala Dewi - Pengaruh Kualitas Layanan Terhadap Loyalitas ...

\begin{tabular}{|c|l|l|l|}
\hline \multirow{4}{*}{ Usia } & $18-26$ Tahun & 53 & $24,1 \%$ \\
& $27-35$ Tahun & 85 & $38,6 \%$ \\
& $36-44$ Tahun & 67 & $30,5 \%$ \\
& $45-50$ Tahun & 15 & $6,8 \%$ \\
\hline & Total & 220 & $100 \%$ \\
\hline
\end{tabular}

Berdasarkan tabel 3 dapat diketahui bahwa dari 220 responden, berdasarkan jenis kelamin menunjukkan bahwa responden yang paling banyak dijumpai di Dunkin' Donuts di Surabaya dan Sidoarjo adalah responden yang berjenis kelamin perempuan sebanyak 144 responden $(65,5 \%)$. Penyebaran angket dilakukan di gerai Dunkin' Donuts pada siang sampai sore hari, sehingga dapat disimpulkan bahwa pada jam-jam makan siang hingga sore hari pelanggan Dunkin' Donuts di Surabaya dan Sidoarjo sebagian besar berjenis kelamin perempuan. Karena pada jam-jam tersebut perempuan lebih banyak menghabiskan waktunya diluar rumah untuk berkumpul bersama teman, keluarga, maupun koleganya.

Berdasarkan usia responden yang paling banyak dijumpai di Dunkin' Donuts di Surabaya dan Sidoarjo adalah responen yang berusia 27-35 tahun sebanyak 85 responden $(38,6 \%)$ Hal ini dikarenakan pada jam tersebut merupakan jam istirahat kantor dan juga sampai dengan jam pulang kantor. Pada usia 27-35 tahun orang-orang yang telah bekerja dan termasuk dalam usia muda suka berkumpul dan menghabiskan waktunya ditempat-tempat ramai seperti cafe, berbeda dengan responden pada usia 36-44 tahun dan juga usia 45-50 tahun yang lebih suka makan siang di dalam kantor dan ketika jam pulang kantor lebih suka langsung pulang kerumah. untuk responden usia 18-26 tahun pada siang hari masih berada di sekolah dan responden pada usia ini lebih suka mencoba hal-hal baru sehingga tingkat loyalitas nya kepada penyedia jasa masih lemah.

\section{Hasil Uji Asumsi Analisis Jalur \\ Hasil Uji Asumsi}

Berdasarkan hasil uji normalitas data yang telah dilakukan diketahui nilai critical rasio skewness value masing-masing variabel menunjukkan distribusi normal. Uji normalitas multivariate sebesar 0,291 juga berdistribusi normal karena masing2 berada dalam rentang -2,58 hingga 2,58, sehingga dapat disimpulkan bahwa asumsi multivariate Merancang Model (Diagram Jalur) normality sudah terpenuhi sehingga data layak digunakan dalam estimasi berikutnya.

Selanjutnya dilakukan uji linieritas, dari uji ini dapat diketahui bahwa nilai sig. kualitas layanan terhadap kepuasan pelanggan sebesar $0,000<0,05$. Nilai kepuasan pelanggan terhadap loyalitas pelanggan sebesar $0,000<0,05$. Nilai kualitas layanan terhadap loyalitas pelanggan juga sebesar $0,000<0,05$. Sehingga telah memenuhi syarat hubungan antar variabel dan bersifat linear. maka dari itu variabel-variabel tersebut layak digunakan untuk estimasi selanjutnya.

Setelah kedua uji asumsi di atas dilakukan yang ketiga yaitu dilakukan uji outlier. Hasil uji outlier menunjukkan hasil pemeriksaan dengan mahalobis distance menunjukkan bahwa tidak terdapat pengamatan yang terdeteksi sebagai outlier. Hal tersebut dikarenakan nilai mahalobis distance yang kurang dari 37,566 dan nilai p2 juga tidak menunjukkan adanya data outlier karena memiliki nilai lebih dari 0,05. Sehingga dapat disimpulkan data tersebut memenuhi asumsi uji outlier dan data layak digunakan dalam estimasi berikutnya.

\section{Hasil Uji Kelayakan Model}

Berdasarkan pengolahan data diperoleh hasil perhitungan ketepatan model sebesar $70 \%$. menerangkan bahwa kontribusi model untuk menjelaskan hubungan struktural dari ketiga variabel yang diteliti sebesar $70 \%$

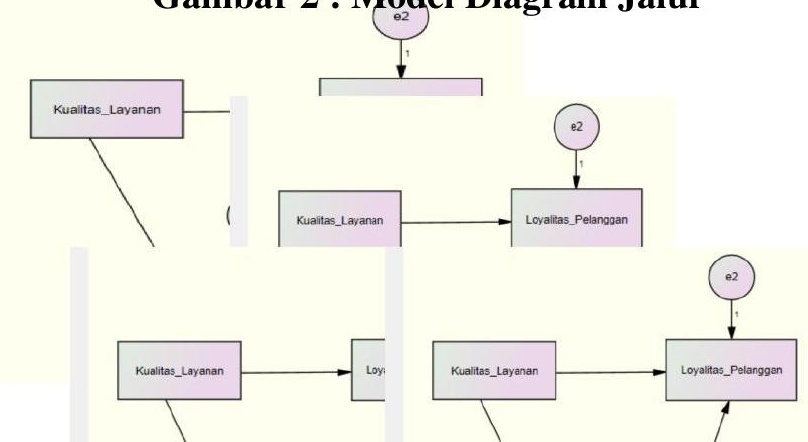


BISMA - Bisnis dan Manajemen -Volume 9 No. 1 Oktober 2016

0,717

0,282

\section{Sumber: Diolah peneliti}

Mengkonversi Diagram Jalur kedalam Persamaan

untuk menghitung nilai e1 dan e2 dapat menggunakan rumus $\mathrm{e}=\sqrt{ } 1-\mathrm{r} 2$.

$\mathrm{Z}=\mathrm{b}_{1} \mathrm{X}+\mathrm{e}_{1} \quad \square \mathrm{Z}=0,717 \mathrm{X}+0,697$

$\mathrm{Y}=\mathrm{b}_{2} \mathrm{Z}+\mathrm{b}_{3} \mathrm{X}+\mathrm{e}_{2} \quad \quad \square=0,282 \mathrm{Z}+0,387 \mathrm{X}+0,783$

Squared Multiple Correlations (Koefisien determinasi)

1. Besarnya perubahan variabel Kepuasan pelanggan yang disebabkan oleh adanya kontribusi variable kualitas layanan adalah 0,514 atau dengan kata lain pengaruh variabel kualitas layanan terhadap kepuasan pelanggan sebesar 51,4\%. Sedangkan sebesar 0,486 dipengaruhi oleh variabel lain.

2. Besarnya perubahan variabel loyalitas pelanggan yang disebabkan oleh adanya kontribusi variabel kualitas layanan dan kepuasan pelanggan adalah 0,386 atau dengan kata lain pengaruh variabel kualitas layanan terhadap loyalitas pelanggan sebesar $38,6 \%$. Sedangkan sebesar 0,614 dipengaruhi oleh variabel

lain. 
Kiki Amelia Nurmala Dewi - Pengaruh Kualitas Layanan Terhadap Loyalitas ...

\section{Hasil Uji Hipotesis}

Tabel 4 Hasil Uji Hipotesis

\begin{tabular}{|l|l|l|l|l|l|l|}
\hline & Variabel & $\begin{array}{l}\text { Standardi } \\
\text { zed }\end{array}$ & $\begin{array}{l}\text { Unstandardi } \\
\text { zed }\end{array}$ & S.E. & C.R & P \\
\hline H1 & Estimate & Estimate & & & \\
& $\begin{array}{l}\text { Kepuasan } \\
\text { Kualitas } \\
\text { Layanan }\end{array}$ \\
\hline H2 & 0,717 & 0,270 & 8 & 15,219 & 0,00 \\
& $\begin{array}{l}\text { Loyalitas } \\
\text { Pelanggan } \\
\text { Kepuasan } \\
\text { Pelanggan }\end{array}$ & 0,282 & 0,213 & 7 & 3,709 & 0 \\
\hline H3 & $\begin{array}{l}\text { Loyalitas } \\
\text { Pelanggan } \\
\text { Kualitas } \\
\text { Layanan }\end{array}$ & 0,387 & 0,110 & 2 & 5,100 & 0 \\
\hline
\end{tabular}

Dari tabel 4 di atas dapat diketahui bahwa :

1. Pada hipotesis pertama terdapat nilai CR hitung antara variabel kualitas layanan terhadap kepuasan pelanggan adalah sebesar $15,219>2,00$ nilai probabilitas signifikansinya sebesar $0,000(\mathrm{p} \leq 0,05)$. Hal ini menunjukkan bahwa variabel kualitas layanan memiliki pengaruh yang signifikan terhadap variabel kepuasan pelanggan. Artinya hipotesis pertama diterima.

2. Pada hipotesis kedua terdapat nilai CR hitung antara variabel kepuasan pelanggan terhadap loyalitas pelanggan adalah sebesar 3,709>2,00 nilai probabilitas signifikansinya sebesar $0,000(\mathrm{p} \leq 0,05)$. Hal ini menunjukkan bahwa variabel kepuasan pelanggan memiliki pengaruh yang signifikan terhadap variabel loyalitas pelanggan. Artinya hipotesis kedua diterima.

3. Pada hipotesis ketiga terdapat nilai CR hitung antara variabel kualitas layanan terhadap loyalitas pelanggan adalah sebesar $5,100>2,00$ nilai probabilitas signifikansinya sebesar $0,000(\mathrm{p} \leq 0,05)$. Hal ini menunjukkan bahwa variabel kualitas layanan memiliki pengaruh yang signifikan terhadap variabel loyalitas pelanggan. Artinya hipotesis ketiga diterima.

\section{Hasil Uji Direct, Indirect, Total Effect}

Pengaruh langsung dari variabel kualitas layanan (X) terhadap kepuasan pelanggan (Z) yaitu sebesar 0,717. Pengaruh langsung dari variabel kepuasan pelanggan $(Z)$ terhadap variabel loyalitas pelanggan (Y) yaitu sebesar 0,282 . Sedangkan pengaruh langsung kualitas layanan (X) terhadap variabel loyalitas pelanggan (Y) yaitu sebesar 0,387 . Hasil tersebut menunjukkan korelasi kualitas layanan dengan kepuasan pelanggan memiliki kekuatan relatif $1,85 \mathrm{x}$ lebih besar daripada korelasi kualitas layanan dengan loyalitas pelanggan.

\section{Hasil Uji Mediasi}

Pada penelitian ini, mediasi terbukti secara parsial (partially mediated).

\section{PEMBAHASAN}

\section{Pengaruh Kualitas Layanan Terhadap Kepuasan Pelanggan}

Penelitian ini menunjukkan bahwa melalui analisis path diperoleh hasil yang memperlihatkan adanya hubungan positif antara kualitas layanan dengan kepuasan pelanggan yang ditunjukkan pada hasil uji hipotesis adalah sebesar $15,219>2,00$. Ada atau tidaknya pengaruh variabel kualitas layanan terhadap kepuasan pelanggan dapat dilihat dari nilai probabilitasnya $\leq 0,05$. Nilai probabilitas kualitas layanan terhadap kepuasan pelanggan signifikansinya adalah sebesar $0,000$ ( $p \leq 0,05)$. Hal ini menunjukkan bahwa variable kualitas layanan memiliki pengaruh yang signifikan terhadap variabel kepuasan pelanggan. Besarnya pengaruh kualitas 


\section{BISMA - Bisnis dan Manajemen -Volume 9 No. 1 Oktober 2016}

layanan terhadap kepuasan pelanggan dapat dilihat dalam Standardized Direct Effect yaitu sebesar 0,717.

Hasil tersebut menunjukan bahwa apabila kualitas layanan baik maka kepuasan pelanggan akan meningkat pula. Hal tersebut menjelaskan bahwa semakin baik kualitas layanan yang didapat oleh pelanggan Dunkin' Donuts maka semakin baik pula penilaian terhadap Dunkin' Donuts, sehingga dapat meningkatkan kepuasan pelanggannya. Hasil tersebut menunjukkan bahwa hipotesis pertama yaitu "Kualitas Layanan berpengaruh positif dan signifikan terhadap kepuasan pelanggan pada pelanggan Dunkin' Donuts di Surabaya dan Sidoarjo" terbukti kebenarannya.

Hasil penelitian ini sesuai dengan teori yang dikemukakan oleh Irawan (2002:38) bahwa kualitas layanan adalah salah satu faktor pendorong untuk mencapai kepuasan pelanggan. Kualitas layanan adalah driver yang paling sulit ditiru. Oleh karena itu kualitas layanan harus dibentuk dan dikelola dengan baik karena hal tersebut akan menjadi stimuli pemasar kepada pelanggan, sehingga pelanggan akan mencapai kepuasan terhadap Dunkin' Donuts. Disamping itu pihak Dunkin' Donuts juga harus terus menerus berupaya untuk meningkatkan kualitas produk dan image perusahaan yang baik

Dapat terjadi hubungan yang positif dan signifikan karena para responden telah merasakan kualitas layanan yang baik, yang telah diberikan oleh Dunkin' Donuts meliputi kelima dimensi kualitas layanan.. Kelima dimensi kualitas layanan seperti keberwujudan layanan dari kebersihan, kerapian pegawai, dan lainnya karena layanan tidak dapat dilihat dan hanya bisa dirasakan; bantuan dari para pelayan dunkin; perhatian secara pribadi; keandalan Dunkin' Donuts; dan reputasi Dunkin' Donuts telah sesuai dengan harapan dari para pelanggan sebelum bertransaksi di Dunkin' Donuts. Adanya kesesuaian harapan dengan kinerja yang dirasakan inilah yang menjadikan konsumen puas akan layanan yang diberikan oleh Dunkin' Donuts. Dalam penelitian ini variabel kualitas layanan diukur dengan menggunakan lima indikator yaitu Tangibles, Emphaty, Reliability, Responsiveness, dan Assurance.

Kedua indikator yang memiliki skor terendah yaitu emphaty dan responsiveness. Emphaty dengan item pernyataan "kasir Dunkin' Donuts fokus melayani pelanggan sampai transaksi selesai", dan "pelayann Dunkin' Donuts selalu memenuhi permintaan khusus pelanggan" memiliki mean 3,86. Hal ini menunjukkan bahwa responden setuju jika emphaty mempengaruhi kepuasan pelanggan. Karena memperoleh perhatian yang tulus dan individual dari Dunkin' Donuts bagi pelanggan adalah sesuatu yang diharapkan dan diperhitungkan.
Responsiveness, dengan item pernyataan "Dunkin' Donuts menyediakan layanan yang cepat” dan " Pelayan Dunkin' Donuts bersedia membantu pelanggan dengan baik " memiliki nilai mean sebesar 3,86 yang menunjukkan bahwa responden setuju bahwa indikator ini juga mempengaruhi pelanggan untuk mendapatkan kepuasan pada Dunkin' Donuts. Hal ini didasari oleh para pelanggan yang mengkonsumsi jasa membutuhkan bantuan dan pelayanan jasa yang cepat dan tepat dari penyedia jasanya, sehingga Dunkin' Donuts harus mampu melayni dengan cepat dan akurat kepada para pelanggannya.

Indikator pembentuk kepuasan pelanggan yang memiliki skor tertinggi yaitu indikator assurance dengan item pernyataan "Dunkin' Donuts memiliki reputasi yang baik", "Pelayan Dunkin' Donuts konsisten melayani pelanggan dengan sopan", dan "Pelayan Dunkin' Donuts memiliki pengetahuan tentang produk yang baik" memiliki nilai mean tertinggi yaitu sebesar 3,98. Dengan demikian menunjukkan bahwa responden setuju jika indikator assurance merupakam indikator yang berpengaruh dalam mendapatkan kepuasan pelanggan. Sangat penting bagi para pelanggan Dunkin' Donuts untuk mendaptkan jaminan dan kepastian mengenai hal-hal yang berkaitan dengan Dunkin' Donuts. Pengetahuan, kesopansantunan, dan kemampuan para pegawai juga merupakan hal penting yang diperhatikan para pelanggan. Sehingga Dunkin' perlu untuk terus menjaga reputasinya agar tetap dengan memperikan pelatihan kepada para pelayannya agar memiliki pengetahuan yang baik serta berperilaku sopan.

Dikaitkan dengan jawaban responden dan melihat secara umum, bahwa kualitas layanan bila dilakukan secara baik maka akan menghasilkan kepuasan pelanggan yang baik juga. Hasil penelitian ini juga mendukung penelitian sebelumnya yang telah dilakukan oleh Sasongko dan Subagio (2013), Quyet et. al (2015), dan Zafar et. al (2012) yang menyatakan bahwa kualitas layanan berpengaruh signifikan terhadap kepuasan pelanggan.

\section{Pengaruh Kepuasan Pelanggan Terhadap Loyalitas Pelanggan}

Hasil dari penelitian ini menunjukkan bahwa melalui analisis path diperoleh hasil yang memperlihatkan adanya hubungan positif antara kepuasan pelanggan dengan loyalitas pelanggan yang ditunjukkan pada hasil uji hipotesis adalah sebesar 3,709>2,00. Ada atau tidaknya pengaruh variabel kepuasan pelanggan terhadap loyalitas pelanggan dapat dilihat dari nilai probabilitasnya $\leq 0,05$. Nilai probabilitas kepuasan pelanggan terhadap loyalitas pelanggan signifikansinya adalah sebesar $0,000(\mathrm{p} \leq 0,05)$. Hal ini menunjukkan bahwa variabel kepuasan pelanggan 


\section{Kiki Amelia Nurmala Dewi - Pengaruh Kualitas Layanan Terhadap Loyalitas ...}

memiliki pengaruh yang signifikan terhadap variabel loyalitas pelanggan. Besarnya pengaruh Kepuasan pelanggan terhadap loyalitas pelanggan dapat dilihat dalam Standardized Direct Effect yaitu sebesar 0,282.

Hasil tersebut menunjukan bahwa apabila kepuasan pelanggan meningkat maka loyalitas pelanggan akan meningkat pula. Hal tersebut menjelaskan bahwa semakin tinggi kepuasan pelanggan Dunkin' Donuts di Surabaya dan Sidoarjo yang didapatkan maka semakin tinggi pula loyalitas pelanggan yang akan dilakukan pelanggan di masa yang akan datang. Dengan begitu maka hipotesis kedua yaitu "Kepuasan pelanggan berpengaruh positif dan signifikan terhadap loyalitas pelanggan pada pelanggan Dunkin' Donuts di Surabaya dan Sidoarjo" terbukti kebenarannya.

Hasil penelitian ini sesuai dengan teori yang dikemukakan oleh Sumarwan, (2011:386) Di dalam suatu proses keputusan, konsumen tidak akan berhenti hanya sampai proses konsumsi. Konsumen akan melakukan proses evaluasi terhadap konsumsi yang telah dilakukannya, inilah yang disebut sebagai evaluasi alternatif pascapembelian atau pascakonsumsi. Setelah mengkonsumsi suatu produk atau jasa, konsumen akan memiliki perasaan puas atau tidak puas terhadap produk yang dikonsumsinya. Kepuasan akan mendorong konsumen membeli dan mengkonsumsi ulang produk tersebut. Oleh karena itu Dunkin' Donuts harus mengupayakan semua pelanggan mencapai kepuasan pada setiap kali bertransaksi di Dunkin' Donuts agar loyalitas pelanggan dapat terbentuk.

Terjadi nya hubungan yang positif dan signifikan antara kepuasan pelanggan terhadap loyalitas pelanggan yaitu dikarenakan para responden yang telah merasakan puas cenderung berniat melakukan pembelian ulang pada suatu penyedia jasa. Sehingga pelanggan yang puas akan berpengaruh positif pada loyalitas pelanggan. Harapan yang terlampaui dapat menjadikan konsumen sangat puas hal inilah yang memicu terbentuknya loyalitas pelanggan. Pelanggan yang puas bersedia membayar dengan harga yang tinggi, lebih toleran terhadap kesalahan, loyal terhadap perusahaan, dan juga sampai bersedia untuk melakukan word of mouth.

Dalam penelitian ini variabel kepuasan pelanggan diukur dengan menggunakan empat indikator yaitu tidak ada keluhan, perasaan puas pelanggan pada produk atau jasa, kesesuaian dengan harapan pelanggan, dan harapan pelanggan yang terlampaui. Berdasarkan hasil dari jawaban responden melalui pernyataan-pernyataan dalam mengukur kepuasan pelanggan, indikator yang memiliki skor tertinggi yaitu indikator kesesuaian dengan harapan pelanggan memiliki nilai mean sebesar 4,01. Hal ini menunjukkan bahwa responden setuju bahwa indikator ketiga berpengaruh dalam membentuk loyalitas. Para pelanggan di Dunkin' Donuts memiliki harapan jasa yang diterima nya sesuai dengan apa yang diinginkannya, ketika hal tersebut terpenuhi maka kepuasan pun tercapai dan kemudian membuat loyalitas terbentuk. Dunkin' Donuts dituntut untuk bisa membaca seperti apa harapan dari para pelanggannya agar hapan para pelanggan tersebut dapat sesuai dalam pemenuhannya.

Indikator dengan skor terendah yaitu harapan pelanggan yang terlampaui memiliki nilai mean sebesar 3,71 yang menunjukkan bahwa para responden setuju salah satu pembentuk loyalitas didasarkan pada harapan pelanggan yang terlampaui. Pelanggan akan sangat puas ketika apa yang didapatkannya melebihi apa yang telah diharapkan. Kepuasan ini yang kemudian menjadikan pelanggan untuk memilih loyal pada Dunkin' Donuts.

Dikaitkan dengan jawaban responden dan melihat secara umum, bahwa bila kepuasan pelanggan telah dirasakan dengan baik maka akan menumbuhkan loyalitas pelanggan dimasa yang akan datang kepada Dunkin' Donuts. Hasil penelitian ini juga mendukung penelitian yang dilakukan oleh Sachro (2013) dan Aryani \& Rosinta (2010) yang menyatakan bahwa kepuasan pelanggan berpengaruh terhdap loyalitas pelanggan.

\section{Pengaruh Kualitas Layanan Terhadap Loyalitas Pelanggan}

Hasil dari penelitian ini menunjukkan bahwa melalui analisis path diperoleh hasil yang memperlihatkan adanya hubungan antara kualitas layanan dengan loyalitas pelanggan yang ditunjukkan pada hasil uji hipotesis adalah sebesar 5,100<2,00. Ada atau tidaknya pengaruh variabel kualitas layanan terhadap loyalitas pelanggan dapat dilihat dari nilai probabilitasnya $\leq 0,05$. Nilai probabilitas kualitas layanan terhadap loyalitas pelanggan signifikansinya adalah sebesar $0,000(\mathrm{p} \geq 0,05)$. Hal ini menunjukkan bahwa variabel kualitas layanan memiliki pengaruh yang signifikan terhadap variabel loyalitas pelanggan. Besarnya pengaruh kualitas layanan terhadap loyalitas pelanggan dapat dilihat dalam Standardized Direct Effect yaitu sebesar 0,387.

Hasil tersebut menunjukan bahwa apabila kualitas layanan baik maka loyalitas pelanggan terhadap Dunkin' Donuts juga ikut meningkat. Hal tersebut menjelaskan bahwa semakin baik kualitas layanan yang didapat oleh pelanggan Dunkin' Donuts maka loyalitas pelanggan terhadap Dunkin' Donuts akan meningkat juga. Dengan begitu maka hipotesis ketiga yaitu "Kualitas layanan berpengaruh positif dan signifikan terhadap loyalitas 


\section{BISMA - Bisnis dan Manajemen -Volume 9 No. 1 Oktober 2016}

pelanggan pada pelanggan Dunkin' Donuts di Surabaya dan Sidoarjo" terbukti kebenarannya.

Hasil penelitian ini sesuai dengan teori yang dikemukakan oleh Tjiptono, (2007:204) Kualitas pelayanan mempunyai hubungan yang kuat dengan perusahaan yang menyediakan pelayanan jasa kepadanya, dengan kualitas pelayanan yang baik pada akhirnya dapat menciptakan kesetiaan atau loyalitas pelanggan terhadap perusahaan yang memberikan pelayanan yang menyenangkan. Oleh karena itu Dunkin' Donuts harus memberikan kualitas layanan yang baik kepada para pelanggannya agar loyalitas dapat tercipta dari para pelanggan. Loyalitas merupakan keuntungan jangka panjang yang akan diterima dari para pelanggan yang menyenangi kualitas layanan yang diberikan.

Penyebab terjadinya hubungan yang signifikan antara kualitas layanan yang terhadap loyalitas pelanggan yaitu karena responden yang telah merasakan kualitas layanan yang baik dari Dunkin' Donuts akan loyal terhadap Dunkin' Donuts. Para pelanggan akan membandingkan kinerja dari Dunkin' Donuts meliputi kebersihan area Dunkin' Donuts, layanan yang cepat, kesesuaian pesananan, reputasi yang baik, perhatian individu. Ketika kinerja tersebut melebihi harapan pelanggan sebelum bertransaksi pada Dunkin' Donuts maka loyalitas pun dapat terbentuk. Selain kepuasan yang berulang-ulang juga baru akan menjadikan seseorang loyal terhdap perusahaan. sehingga kualitas yang baik baru akan menyebabkan kepuasan pelanggan. Kepuasan pelanggan yang berulang-ulang dirasakan akan menyebabkan loyalitas pelanggan.

Dalam penelitian ini variabel loyalitas pelanggan diukur dengan tiga indikator yaitu pembelian ulang, rekomendasi, dan tidak mudah dipengaruhi oleh merek lain. Berdasarkan hasil dari jawaban responden melalui pernyataan-pernyataan dalam mengukur kepuasan pelanggan, indikator pembelian ulang memiliki nilai mean sebesar 3,89 yang berarti para responden setuju bahwa kualitas layanan yang baik akan mempengaruhi para pelanggan Dunkin' Donuts untuk melakukan pembelian ulang.

Indikator kedua yaitu rekomendasi memiliki nilai mean sebesar 3,93 yang artinya para respondenn setuju jika kualitas yang baik yang diberikan oleh Dunkin' Donuts akan membuat para pelanggannya merekomendasikan Dunlin' Donuts kepada orang lain. Sehingga Dunkin' Donuts dengan sendirinya mendapatkan para pelanggan baru tanpa harus melakukan kegiatan pemasaran yang terlalu keras untuk mendapatkan pelanggan.

Selain menggunakan kedua indikator di atas, dalam pengukuran loyalitas pelanggan indikator ketiga yaitu tidak mudah dipengaruhi oleh merek lain yang meiliki nilai mean sebesar 3,93. Hal ini menunjukkan responden setuju bahwa kualitas layanan yang baik akan mempengaruhi pelanggan untuk dapat menunjukkan kekebalan terhadap tarikan pesaing sehingga Dunkin' Donuts tidak perlu ragu untuk kehilangan para pelanggannya. Pelanggan yang telah diberi kualitas layanan yang baik akan loyal terhadap Dunkin' Donuts.

Hasil penelitian ini juga mendukung penelitian yang dilakukan oleh Rousan et.al (2010) dan Ivanauskienè \& Volungènaite (2014) yang menyatakan bahwa kualitas layanan berpengaruh terhadap loyalitas pelanggan.

\section{KESIMPULAN}

Berdasarkan hasil penelitian dan pembahasan maka dapat disimpulkan sebagai berikut: (1) Terdapat pengaruh yang signifikan dari kualitas layanan $(\mathrm{X})$ terhadap kepuasan pelanggan (Z) pada Pelanggan Dunkin' Donuts di Surabaya dan Sidoarjo.(2) Terdapat pengaruh yang signifikan dari kepuasan pelanggan $(Z)$ terhadap loyalitas pelanggan (Y) pada Pelanggan Dunkin' Donuts di Surabaya dan Sidoarjo.(3) Terdapat pengaruh yang signifikan dari kualitas layanan (X) terhadap loyalitas pelanggan (Y) pada Pelanggan Dunkin' Donuts di Surabaya dan Sidoarjo.

Saran bagi penelitian selanjutnya: (1) Bagi peneliti selanjutnya disarankan untuk menggunakan variabel independen selain kualitas layanan. Karena kontribusi variabel kualitas layanan dan kepuasan hanya memiliki pengaruh sebesar 38,6\% sehingga masih ada $61,4 \%$ variabel lain yang mempengaruhi loyalitas pelanggan. Peneliti selanjutnya lebih disarankan untuk mengkombinasikan variabel pendorong kepuasan lainnya selain kualitas layanan. seperti kualitas produk, harga, emosional factor, serta biaya \& kemudahan. (2) Bagi peneliti selanjutnya disarankan untuk melakukan penyebaran angket di Dunkin' Donuts Surabaya dan Sidoarjo yang letaknya strategis pada akhir pekan. Hal ini berdasarkan pengalaman, yang didapatkan peneliti bahwa Dunkin' Donuts yang memiliki letak strategi lebih ramai dikunjungi oleh para pelanggan pada akhir pekan.

\section{REFERENSI}

Alma, Buchari. 2007. Manajemen Pemasaran \& Pemasaran Jasa. Bandung: CV. Alfabeta

Andreani, Fransisca, Taniaji, T.L., \& Puspitasari, R.N.M. 2012. "The Impact of Brand Image, Customer Loyalty with Customer Satisfaction as A Mediator in Mcdonald's". Jurnal Manajemen dan Kewirausahaan. Vol 14 (1): pp 63-70 
Kiki Amelia Nurmala Dewi - Pengaruh Kualitas Layanan Terhadap Loyalitas ...

Aryani, Dwi \& Rosinta, Febrina. 2010. "Pengaruh Kualitas Layanan terhadap Kepuasan Pelanggan dalam Membentuk Loyalitas Pelanggan". Jurnal Ilmu Administrasi dan Organisasi. Vol. 17 (2) pp: 114-126

Baron, R.M., \& Kenny, D.A. 1996. "The ModeratorMediator Variable Distinction in Social Psychological Research: Conceptual, Strategic, and Statictical Considerations. Journal of Personality and Social Psychology”. Vol. 51(6) pp: 1173-1182

Engel, J.F., Blackwell, R.D., \& Miniard, P.W. 1995. Perilaku Konsumen. Jakarta : Binarupa Aksara

Ghozali, Imam. 2013. Aplikasi Analisis Multivariate Dengan Program SPSS. Edisi Keempat. Semarang: Badan Penerbit Universitas Diponegoro.

Griffin, Jill. 2005. Customer Loyalty. Jakarta: Erlangga

Hurriyati, Ratih. 2010. Bauran Pemasaran dan Loyalitas

Konsumen. Bandung: CV Alvabeta.

Irawan, Deny \& Japarianto, Edwin. 2013. "Analisa Pengaruh Kualitas Produk Terhadap Loyalitas Melalui Kepuasan Sebagai Variabel Intervening Pada Pelanggan Restoran Por Kee Surabaya”. Jurnal Manajemen Pemasaran. Vol. 1 (2) pp: 1-8

Irawan, Handy. 2002. 10 Prinsip Kepuasan Pelanggan. Jakarta: PT Elex Media

Ivanauskienè, Neringa \& Volungènaitè, Justina. 2014. "Relations between Service Quality and Customer Loyalty: An Empirical Investigation of Retail Chain Stores in Emerging Markets". American International Journal of Social Science. Vol. 3 (2) pp: 113-120

Jajak Pendapat, (Online), http://jakpat.net/donuts-ohdonuts-dunkin-donuts-vs-j-co-donuts-in-indonesia/ , (diakses 20 april 2016)

Kotler, Philip \& Keller, L Kevin. 2009. Manajemen Pemasaran Jilid 1 Edisi 13. Jakarta: Erlangga

Kuliner Kota, (Online), https://kulinerkota.wordpress.com/ alamat-restoran-waralaba/surabaya/dunkin-donutssurabaya/, (diakses 03 Agustus 2016)

Lupiyoadi, Rambat. 2014. Manajemen Pemasaran Jasa Berbasis Kompetensi Edisi 3. Jakarta: Salemba Empat

Malhotra, Naresh K. 2009. Riset Pemasaran Pendekatan Terapan Jilid 1 Edisi keempat.Jakarta: Indeks

Quyet, T.V., Vinh, N.Q., \& Chang, Taikoo. 2015. "Service Quality Effects on Customer Satisfaction in Banking Industry". International Journal of $u$ - and e-Service, Science and Technology. Vol. 8 (8) pp: 199-206

Ramseook, Prabha \& Munhurrun. 2012. "Perceived Service Quality In Restaurant Services: Evidence From Mauritius”. International Journal Of Management And Marketing Research. Vol. 5 (3) pp: 1-14
Rousan, Al., M. Ramzi, Badaruddin Mohamed. 2010. "Customer Loyalty and the Impacts of Service Quality: The Case of ive Star Hotels in Jordan". International Journal of Human and Social Sciences. Vol. 5 (13) pp: 886-892

Sachro. 2013. "The Effect Service Quality to Customer Satisfaction and Customer Loyalty". IOSR Journal of Business and Management. Vol. 12 (1) pp: 33-38

Sarwono, Jonathan dan Tutty Martadireja. 2008. Riset Bisnis untuk Pengambilan Keputusaan. Yogyakarta: Andi.

Sarwono, Jonathan. 2010. Metode Penelitian Kuantitatif \& Kualitatif. Yogyakarta: Graha Ilmu

Sasongko, Felita \& Subagio, Hartono. 2013. "Pengaruh Kualitas Layanan Terhadap Kepuasan Pelanggan Restoran Ayam Penyet Ria". Jurnal Manajemen Pemasaran Petra. Vol. 1 (2) pp: 1-7

Setiawan, Ivan Aries dan Ritonga, Ferdiansyah. 2011. Analisis jalur (Path Analysis) Dengan Menggunakan Program AMOS. Tangerang: Suluh Media.

Siddiqi, K Omar. 2011. "Interrelations between Service Quality Attributes, Customer Satisfaction and Customer Loyalty in the Retail Banking Sector in Bangladesh". International Journal of Business and Management. Vol. 6 (3) pp: 12-36

Simamora, Bilson. 2005. Analisis Multivariat Pemasaran. Jakarta: PT Gramedia Pustaka Utama.

Solimun. 2005. Structure Equation Modeling (SEM) lisrel \& Amos. Malang: Fakultas MIPA Universitas Brawijaya Malang. Sugiyono. 2014. Metode Penelitian Bisnis. Bandung: Alfabeta. Sumarwan, Ujang. 2011. Perilaku Konsumen Teori dan Penerapannya dalam Pemasaran. Bogor: Ghalia Indonesia Tjiptono, Fandy \& Chandra, Gregorius. 2007. Service, Quality \& Satisfaction, Edisi 2. Yogyakarta: ANDI

Tjiptono, Fandy \& Diana, Anastasia. 2015. Pelanggan Puas? Tak Cukup!. Yogyakarta: ANDI

Top Band Indeks 2015 Fase 2, (Online), http://www.topbrand-award.com/top-brandsurvey/survey-result, (diakses 10 desember 2015)

Website Dunkin' Donuts, (Online), http://www.dunkindonuts.co.id/about.php , (diakses 12 desember 2015)

Wijaya, Tony. 2009. Analisis Structural Equation Modelling menggunakan AMOS. Yogyakarta: Universitas Atma Jaya.

Zafar, Mohsin et. al. 2012. "Service Quality, Customer Satisfaction and Loyalty: An Empirical Analysis of Banking Sector in Pakistan". Information Management and Business Review. Vol. 4 (3) pp: 159-167 


\section{BISMA - Bisnis dan Manajemen -Volume 9 No. 1 Oktober 2016}

www.kemenperin.go.id/artikel/10589/Target-PertumbuhanIndustri-2015-Dipangkas-Jadi-6,1 , (diakses 7 desember 2015)

http://beritadaerah.co.id/2015/08/27/bisnis-waralababertumbuh- mencapai-20-tahun-2015/, (diakses 7 desember 2015) 7 http://www.bungasari.com/flour_power/flour_101_detail/21 4/Perk embangan-Industri-Tepung-Terigu-di-Indonesia , (diakses 20 april 2016)

http://quantpsy.org/sobel/sobel.html, diakses 29 juni 2016) 